\title{
STUDI MIKROBIA DAN BIOKIMIA FERMENTASI BIJI KAKAO KERING
}

\author{
Mulono Apriyanto ${ }^{(1)}$, Rujiah $^{(2)}$ \\ ${ }^{(\mathbf{1})}$ Fakultas Pertanian, Universitas Islam Indragiri \\ ${ }^{(2)}$ Dinas Tanaman Pangan, Hortikultura dan Peternakan Kab. INHIL \\ mulonoapriyanto71@gmail.com
}

\begin{abstract}
Abstrak
Penelitian ini bertujuan mempelajari parameter fermentasi biji kakao kering secara kuantitatif dan sudut pandang kualitatif, sehingga lebih efektif menentukan peran dan fungsi mikroorganisme. Ketiga cara fermentasi yaitu kontrol (tanpa penambahan inokulum), selanjutnya inokulum Sacharomyces cerevisiae (FNCC 3056), Lactobacillus lactis (FNC 0086) dan Acetobacter aceti (FNCC 0016), masing-masing sekitar $108 \mathrm{cfu} / \mathrm{g}$ diberikan serentak diawal fermentasi (A) dan ketiga inokulum diberikan secara bertahap (B) di awal fermentasi ditambahkan Sacharomyces cerevisiae (FNCC 3056), selanjutnya jam ke 24 ditambahkan Lactobacillus lactis (FNC 0086) dan Acetobacter aceti (FNCC 0016) pada jam ke 48 selanjutnya difermentasi hingga jam ke 120. Hasil penelitian menunjukan bahwa terjadi penurunan kadar gula total, $\mathrm{pH}$ dan total polifenol pada ketiga perlakuan selama fermentasi. Konsentrasi etanol, asam laktat dan asam asetat pada semua perlakuan mencapai jumlah puncaknya berturut-turut pada jam ke 24, 60 dan 108 fermentasi. Sacharomyces cerevisiae, Lactobacillus lactis dan Acetobacter aceti dari ketiga perlakuan mencapai populasi tertinggi berturut-turut pada jam ke 24, 48 dan 72 fermentasi.
\end{abstract}

Kata Kunci : mikrobia, fermentasi, biji kakao kering.

\section{PENDAHULUAN}

Pasca panen biji kakao segar ditingkat petani terdapat 2 cara yaitu biji kakao terfermentasi dan biji kakao kering tanpa fermentasi. Produksi kakao tahun 2011 sebesar \pm 5.450 .000 ton terdiri biji kakao tanpa fermentasi \pm 385.000 ton sisanya merupakan biji kakao hasil fermentasi (Permana dkk, 2012). Padahal biji kakao kering tanpa proses fermentasi dihasilkan biji kakao dengan cita rasa pahit dan tidak dihasilkan aroma khas kakao (Caponio dkk, 2020).
Senyawa prekusor flavor biji kakao dapat terbentuk melalui proses fermentasi. Pada saat Fermentasi terbagi menjadai dua. Pertama diawali pelepasan pulp dan kedua terjadinya reaksi hidrolitik didalam kotiledon biji. Pada tahap kedua diawali dengan proses suksesi mikrobia (Apriyanto dkk, 2017). Fermentasi kakao berlangsung selama 120 jam atau 6 hari serta dilakukan pembalikan dihari ke 2, 3, 4 dan 5 . Diawal fermentasi $S$. cerevisiae merupakan mikrobia yang berperan diawal fermentasi. Hal ini dikarena $S$. cerevisiae mempu tumbuh dengan baik 
dan toleran terhadap etanol, $\mathrm{pH}$ rendah sejalan aktivitas pektinolitik. L. lactis, toleran terhadap lingkungan asam dengan kandungan oksigen banyak. Bakteri diakhir fermentasi didominasi A. aceti mampu tumbuh pada $\mathrm{pH}$ 3,5 serta kosentrasi etanol rendah. Selanjutnya etanol teroksidasi menjadi asam asetat dan menjadi $\mathrm{CO}_{2}$ dan air (Apriyanto dkk, 2016). Alkohol dan asam asetat akan terdidifusi kedalam keping biji seiring naiknya suhu lingkungan dan kematian biji (Afoakwa, 2014).

\section{METODE PENELITIAN}

Buah kakao yang digunakan dari jenis lindak berasal dari desa Bunder, Yogyakarta. Ciri buah seperti gambar 1 . dengan karakteristik yaitu panjang buah $\pm 16 \mathrm{~cm}$, diameter $\pm 9 \mathrm{~cm}$. Metoda fermentasi mengacu pada penelitian (Apriyanto dkk., 2017). Fermentasi dilakukan dalam tiga teknik. Teknik I difermentasi secara spontan (tanpa inokulum) sebagai perlakuan kontrol. Teknik kedua (A) adalah penambahan biakan murni $S$. Cerevisiae (FNCC 3056), L. lactis (FNC 0086) dan A. aceti (FNCC0016) secara serentak pada awal. Teknik ketiga (B) penambahan biakan murni secara bertahap, penambahan biakan murni $S$. Cerevisiae (FNCC 3056) pada awal fermentasi jam ke 0 , selanjutnya L. lactis (FNC 0086) setelah 24 jam, kemudian A. aceti setelah 72 jam, selanjutnya diinokulasi.

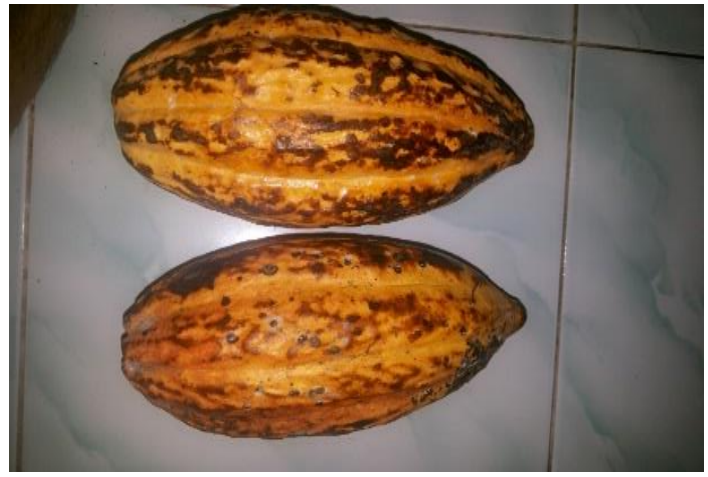

Gambar 1. Buah kakao masak optimum

Keberhasilan fermentasi dievaluasi dengan perubahan kadar gula total, $\mathrm{pH}$, total polifenol, $S$. cerevisiae (FNCC 3056), L. lactis (FNC 0086), A. aceti (FNCC0016), total polifenol, kosentrasi etanol, asam laktat dan asam asetat.

\section{HASIL DAN PEMBAHASAN}

Hasil penelitian menunjukan suhu awal perlakuan kontrol, A dan B berturut - turut yaitu 28,29 dan $29,5^{\circ}$ C. Suhu fermentasi tertinggi untuk perlakuan kontrol, A dan B berturut - turut yaitu 38,42 dan $51{ }^{\circ} \mathrm{C}$. Suhu fermentasi di 120 jam untuk perlakuan kontrol, A dan B berturut - turut yaitu 35,38 dan $39^{\circ} \mathrm{C}$.

Perubahan suhu fermentasi penelitian iini sejalan dengan hasil yang diperoleh Apriyanto dkk., (2016) yang telah mempelajari perbaikan proses fermentasi biji kakao kering. Pada perlakuan secara bertahap kemungkinan S. cerevisiae merombak gula pulp lebih banyak sehingga dihasilkan etanol lebih besar serta pada saat yang tepat etanol di ubah menjadi asam asetat oleh A. aceti dimana reaksi perombakan etanol menjadi asam asetat juga menghasilkan panas yang menyebabkan suhu fermentasi meningkat. Penambahan inokulum secara serentak menghasilkan suhu kematian biji tidak dicapai dapat 
diduga terjadi persaingan antar $S$. termasuk manitol dan inositol kurang cerevisiae dan L. lactis. Gula total biji dari $0,50 \mathrm{mg} / \mathrm{g}$ (Afoakwa dkk, 2013). kakao kering seluruh pelakuan Gula total biji kakao kering diawal mengalami penurunan sampai 120 jam. fermentasi perlakuan kontrol, A dan B Gula dalam biji kakao adalah sukrosa, berturut - turut yaitu 8,45; 8,45 dan fruktosa dan glukosa (Afoakwa, 2010) 8,5\% selanjutnya diakhir fermentasi dengan sukrosa (90 \% dari total gula), berturut - turut yaitu 3,07; 2,60 dan diikuti oleh fruktosa dan glukosa yaitu 6 2,70\%.

$\%$ dari total gula ( 0,9 dan $0,7 \%)$ dan

Tabel 1. Hasil analisis statistik perubahan kadar gula total, $\mathrm{pH}$, total polifenol, etanol, asam laktat, asam asetat, S. Cerevisiae (FNCC 3056), L. lactis (FNC 0086) dan A. aceti (FNCC0016).

\begin{tabular}{lccc}
\hline \multicolumn{1}{c}{ Parameter } & \multicolumn{3}{c}{ Perlakuan } \\
\cline { 2 - 4 } & Control & $\mathrm{A}$ & $\mathrm{B}$ \\
\hline Kadar gula total $(\%, \mathrm{bk})$ & $3,07 \pm 0,67 \mathrm{a}$ & $2,60 \pm 0,65 \mathrm{a}$ & $2,70 \pm 0,7 \mathrm{a}$ \\
Kadar gula reduksi $(\%, \mathrm{bk})$ & $10,53 \pm 0,55 \mathrm{a}$ & $10,63 \pm 0,53 \mathrm{a}$ & $10,57 \pm 0,52 \mathrm{a}$ \\
$\mathrm{pH}$ biji & $4,45 \pm 0,17 \mathrm{a}$ & $4,28 \pm 0,2 \mathrm{a}$ & $4,20 \pm 0,2 \mathrm{a}$ \\
S. cerevisiae $(\log \mathrm{cfu} / \mathrm{g})$ & $3,55 \pm 0,25 \mathrm{a}$ & $2,30 \pm 0,5 \mathrm{a}$ & $2,22 \pm 0,5 \mathrm{a}$ \\
L. lactis $(\log \mathrm{cfu} / \mathrm{g})$ & $5,42 \pm 0,17 \mathrm{a}$ & $6,42 \pm 0,6 \mathrm{~b}$ & $6,23 \pm 0,6 \mathrm{~b}$ \\
A. aceti $(\log \mathrm{cfu} / \mathrm{g})$ & $4,87 \pm 0,47 \mathrm{a}$ & $5,30 \pm 0,8 \mathrm{~b}$ & $9,22 \pm 0,8 \mathrm{~b}$ \\
Etanol $(\%)$ & $0,40 \pm 0,30 \mathrm{a}$ & $0,33 \pm 0,7 \mathrm{a}$ & $0,20 \pm 0,5 \mathrm{a}$ \\
Asam laktat $(\%)$ & $2,00 \pm 0,17 \mathrm{a}$ & $1,82 \pm 0,9 \mathrm{a}$ & $1,70 \pm 0,3 \mathrm{a}$ \\
Asam asetat $(\%)$ & $5,90 \pm 0,28 \mathrm{a}$ & $6,32 \pm 0,2 \mathrm{a}$ & $6,80 \pm 0,6 \mathrm{a}$ \\
Total polifenol & $0,079 \pm 0,14 \mathrm{a}$ & $0,07 \pm 0,05 \mathrm{a}$ & $0,068 \pm 0,2 \mathrm{a}$ \\
(mg asam galat/g) & & & \\
\hline
\end{tabular}

Keterangan : Huruf berbeda dibelakang menunjukan beda nyata $\mathrm{p} \leq 0,05$ Hasil rata-rata 3 ulangan analisis

Gula reduksi perlakuan kontrol, A dan B di awal fermentasi berturut turut yaitu 3,49, 3,63 dan 3,63\%. Setelah 120 jam fermentasi gula reduksi perlakuan kontrol, A dan B berturut turut yaitu 10,53; 10,63 dan 10,57\%.

Derajat keasaman $(\mathrm{pH})$ hasil penelitian sejalan dengan penelitan (Apriyanto dkk 2017) dimana perlakuan kontrol, A dan B menunjukan pH biji kakao kering tidak berbeda nyata seperti terlihat pada tabel 1. pH biji kakao kering pada seluruh perlakuan naik berturut - turut menjadi 4,45, 4,28 dan 4,20 di 120 jam fermentasi.

Populasi S. cerevisiae, L. lactis dan A. aceti di awal fermentasi perlakuan kontrol, A dan B berturut- turut 5,$55 ; 6,66$ dan 4,65 log $(\mathrm{cfu} / \mathrm{g})$; 8,$28 ; 8,58$ dan $8,57 \log (\mathrm{cfu} / \mathrm{g})$; dan 8,$66 ; 6,64$ dan 4,67 log (cfu/g) diakhir fermentasi berturut - turut 3,55; 5,42 dan 4,87 log (cfu/g), 2,30; 6,42 dan 5,30 log (cfu/g); 2,22; 6,23 dan 9,22 log cfu/g sejalan dengan penelitian Kresnowati dkk, (2013), Kustyawati dan Setyani, (2008). Pada seluruh perlakuan diawal fermentasi kosentrasi etanol, asam laktat dan asam asetat seluruhnya $0 \%$. Diakhir fermentasi perlakuan kontrol, A, dan B berturut-turut 0,$40 ; 2,00$; dan $5,90 \%$, $0,33,1,82$ dan $6,32 \% ; 0,20,1,70$ dan $6,80 \%$. Asam asetat merupakan asam organik yang terdifusi kedalam keping biji sehingga mengakibatkan aktifnya enzim polifenol oksidase yang 
mengoksidasi polifenol (Putra dkk, 2012).

Total polifenol perlakuan kontrol, A dan B diawal fermentasi menunjukan berturut - turut yaitu 0,$172 ; 0,178$ dan 0,176 ( $\mathrm{mg}$ asam galat $/ \mathrm{g}$ ), terus turun sampai akhir fermentasi berturut - turut menjadi 0,079, 0,07 dan 0,068 (mg asam galat/g biji) (Apriyanto dan Umanailo, 2019).

\section{KESIMPULAN}

\section{Kesimpulan}

Mutu biji kakao kering setelah difermentasi menunjkkan hasil dapat ditingkatkan. Perlakuan B yaitu penambahan inokulum secara bertahap diakhir fermentasi menunjukan mutu lebih baik dibanding perlakuan lainnya.

\section{Saran}

Kosentrasi penambahan inokulum mikrobia secara tepat perlu dikaji lebih lanjut guna keberhasilan proses fermentasi. Perlu dilakukan penelitian lebih lanjut tentang fermentasi terkendali sekala lebih besar.

\section{DAFTAR PUSTAKA}

Afoakwa, E. O. (2014). Changes in Biochemical and Physico-chemical Qualities during Drying of Pulp Preconditioned and Fermented Cocoa (Theobroma cacao) Beans. Journal of Nutritional Health \& Food Science, 2(3). https://doi.org/10.15226/jnhfs.2014. 00121.

Afoakwa, E. O., Quao, J., Takrama, J., Budu, A. S., dan Saalia, F. K. (2013). Chemical composition and physical quality characteristics of
Ghanaian cocoa beans as affected by pulp pre-conditioning and fermentation. Journal of Food Science and Technology, 50(6), 1097-1105.

https://doi.org/10.1007/s13197-0110446-5

Apriyanto M dan Umanailo, M. C. B. (2019). Decrease polyphenols, ethanol, lactic acid, and acetic acid during fermentation with addition of cocoa beans innoculum. International Journal of Scientific and Technology Research, 8(10). 461-465

Apriyanto, Mulono, Sutardi, S., Harmayani, E., dan Supriyanto, S. (2016). Perbaikan Proses Fermentasi Biji Kakao Non Fermentasi dengan Penambahan Biakan Murni Saccharomyces cerevisiae , Lactobacillus lactis , dan Acetobacter aceti. 36(4).

Apriyanto, Mulono, Sutardi, S., Supriyanto, S., dan Harmayani, E. (2017). Amino acid analysis of cocoa fermented by high performance liquid chromatography (HPLC). Asian Journal of Dairy and Food Research. https://doi.org/10.18805/ajdfr.v36i0 2.7962

Apriyanto Mulono, Sutardi, Supriyadi, dan Harmayani, E. (2017). Fermentasi biji kakao kering menggunakan

Saccharomycescerevisiae

Lactobacillus lactis , Acetobacter aceti. AGRITECH, 37(3), 302-311. https://doi.org/http://doi.org/10.221 46/agritech. 17113

Caponio, G. R., Lorusso, M. P., Sorrenti, G. T., Marcotrigiano, V., Difonzo, G., De Angelis, E., Portincasa, P. (2020). Chemical characterization, gastrointestinal motility and sensory evaluation of dark chocolate: A 
nutraceutical boosting consumers' health. Nutrients, 12(4). https://doi.org/10.3390/nu12040939 Kresnowati, M. T. A. P., Suryani, L., dan Affifah, M. (2013). Improvement of Cocoa Beans Fermentation by LAB Starter Addition. Journal of Medical and Bioengineering, 2(4), 274-278. https://doi.org/10.12720/jomb.2.4.2 74-278.

Kustyawati, M. E., dan Setyani, S. (2008). Pengaruh Penambahan Inokulum Campuran terhadap Perubahan Kimia dan Mikrobiologi selama Fermentasi Coklat. Jurnal Teknologi Industri Dan Hasil Pertanian, 13(2), 73-84.
Permana, I. D. G. M., Indrati, R., dan Hastuti, P. (2012). Optimasi Isolasi Lipase Indigenous Biji Kakao (Theobroma cacao L.) The Optimizing of Isolation of Cocoa Bean Indogenous Lipase (Theobroma cacao L.). Agritech, 32(01), 27-32. https://doi.org/10.22146/agritech.96 53.

Putra, G. P. G., Wartini, N. M., dan A.A.M. Dewi Anggreni. (2012). Karakterisasi Enzim Polifenol Oksidase Biji Kakao (Theobroma cacao Linn.). Agritech, 30(3), 152157. https://doi.org/10.22146/agritech.9 667 